\title{
IMPLIKASI PUTUSAN MAHKAMAH KONSTITUSI NOMOR 11-017/ PUU-I/2003 TERHADAP PERLINDUNGAN HUKUM HAK DIPILIH
}

\author{
Oleh \\ I Ketut Ngastawa ${ }^{1}$
}

\begin{abstract}
Paper that had the title: "Juridical implications of the Constitutional Court Decision Number 011-017/PUU-I/2003 on the Legal Protection for the Rights to be Eelected." This explores two issues: 1) how the legal protection of the settings selected in the state system of Indonesia ;2) what are juridical implications of the Constitutional Court Decision Number 011-017/ PUU-I/2003 on the legal protection for the rights to be elected. To solve both problems, this paper uses normative legal research methods. Approach being used is the statute approach, case approach, and a conceptual approach. Further legal materials collected were identified and analyzed using descriptive analysis techniques. Legal protection for the right to be elected in the state system of Indonesia can be traced from the 1945 opening, the articles in the body of the 1945 Constitution, Article 27 paragraph (1), Article 28D (1) and paragraph (3) and Article 28 paragraph (3) 1945 Second Amendment, MPR Decree Number XVII/ MPR/1998, Article 43 of Law Number 39 of 1999, Article 21 of the Universal Declaration of Human Rights, and Article 25 of the International Covenant on Civil and Political Rights. Discussion of the juridical implications of the Constitutional Court Decision Number 011017/PUU-I/2003 on the legal protection for the rights to be elected have been included: a) only on the juridical implications of representative institutions no longer marked with specified requirements as stipulated in Article 60 letter $g$ of Law Number 12 Year 2003 in Law Number 10 Year 2008; b) juridical implications of the political field for the right to be elected is the absence of any discriminatory treatment in legislative product formed by the House of Representatives and the President as well as products of other legislation forward.
\end{abstract}

Keywords: Juridical Implications of the Constitutional Court Decision Number 011-017/ PUU-I/2003, Legal Protection, the Rights to be Elected

\section{PENDAHULUAN}

\subsection{Latar Belakang}

Pada tanggal 24 Februari 2004

Mahkamah Konstitusi telah menjatuhkan

Putusan Nomor 011-017/PUU-I/2003.

Perkara a quo merupakan uji materiil (judicial review) terhadap ketentuan Pasal 60 huruf g UU Nomor 12 Tahun 2003. Putusan Mahkamah Konstitusi Nomor 011-017/PUUI/2003 amarnya menyatakan: 1)mengabulkan

Mahasiswa Program Magister (S2) Ilmu Hukum Universitas Udayana, Denpasar, Alamat : Jln Letda Jaya No.20C Denpasar, email : iketut-ngastawa@ gmail.com permohonan pengujian undang-undang yang diajukan oleh sebagian Pemohon; 2) menyatakan Pasal 60 huruf g UU Nomor 13 Tahun 2003 Tentang Pemilihan Umum Anggota Dewan Perwakilan Rakyat, Dewan Perwakilan Daerah, dan Dewan Perwakilan Rakyat Daerah bertentangan dengan Undang-Undang Dasar Negara Republik Indonesia Tahun 1945; 3) menyatakan Pasal 60 huruf g UU Nomor 12 Tahun 2003 tidak mempunyai kekuatan hukum mengikat.

Mahkamah Konstitusi dalam perkara a quo mencabut ketentuan Pasal 60 huruf g. Indonesia secara konstitusional melarang 
adanya perlakuan diskriminasi. Dalam UUD 1945 berbagai perlakuan diskriminatif dilarang sesuai Pasal 27 ayat (1), Pasal 28D ayat (1), Pasal 28I ayat (2) yuncto Pasal 1 ayat (3) UU Nomor 39 Tahun 1999 tentang Hak Asasi Manusia yuncto Pasal 21 Deklarasi Universal Hak-Hak Asasi Manusia (DUHAM) dan Pasal 25 Kovenan Internasional Tentang Hak-Hak Sipil dan Politik.

Dalam Putusan a quo salah satu Hakim Konstitusi memberikan pendapat berbeda (dissenting opinion) yang mengatakan bahwa Pasal 60 huruf g seolah-olah tidak selalu sejalan dengan semangat yang terkandung dalam beberapa pasal UUD 1945. Adanya pembatasan tersebut tidak bertentangan dengan ketentuan Pasal 28J ayat (2) dan Pasal 28I ayat (1) UUD 1945 Perubahan Kedua. Sedangkan Mahkamah Konstitusi berpendapat bahwa ketentuan Pasal 60 huruf g tidak relevan dengan upaya rekonsiliasi nasional, Indonesia yang lebih demokratis dan berkeadilan.

Pandangan Mahkamah Konstitusi tersebut adalah sesuai dengan tugas dan wewenangnya sebagai pengawal konstitusi, penafsir konstitusi, pengawal demokrasi ${ }^{2}$ sekaligus sebagai pelindung hak konstitusional warga negara ${ }^{3}$. Dengan tugas dan wewenang tersebut, akhirnya melalui Putusan Mahkamah Konstitusi Nomor 011017/PUU-I/2003 mencabut ketentuan Pasal 60 huruf g dinyatakan bertentangan dengan Konstitusi.

Pencabutan terhadap ketentuan Pasal 60 huruf g karena dinyatakan sebagai

Jimly Asshiddiqie, 2006a, Sengketa Kewenangan Antarlembaga Negara, Jakarta, Konstitusi Press, Cet. I, hlm.105.

Jenedjri M. Gaffar, 2012, Politik Hukum Pemilu, Jakarta, Konstitusi Press, hlm.7. pengingkaran terhadap hak-hak asasi warga negara atau diskriminasi terhadap hak konstitusional (constitutional rights) warga negara terkait keyakinan politik. Pengingkaran tersebut tidak saja pada UUD 1945, UU Nomor 39 Tahun 1999 melainkan juga konvensi internasional tentang hak asasi manusia (UDHR dan ICCPR). Substansi Pasal 60 huruf g merupakan hak politik warga negara yang dimanifestasikan sebagai hak dipilih (hak pilih pasif).

Sesuai dengan ketentuan Pasal 10 ayat (1) UU Nomor 24 Tahun 2003 Tentang Mahkamah Konstitusi menyebutkan bahwa Mahkamah Konstitusi berwenang mengadili pada tingkat pertama dan terakhir yang putusannya bersifat final. Menginggat implikasi atas putusan Mahkamah Konstitusi yang bersifat final and binding serta bersifat erga omnes, maka putusannya langsung memperoleh kekuatan hukum sejak diucapkan dan tidak ada upaya hukum yang dapat ditempuh. ${ }^{4}$ Dengan demikian, dapat dimaknai bahwa di satu sisi putusan Mahkamah Konstitusi memberi jaminan terhadap perlindungan hak asasi manusia, termasuk terhadap perlindungan hak dipilih di sisi lain putusannya bersifat final dan tidak ada upaya hukum lain serta mengikat semua pihak.

Berdasarkan uraian di atas menunjukkan bahwa keberadaan Pasal 60 huruf g UU Nomor 12 Tahun 2003 tidak saja menunjukkan adanya konflik norma melainkan normanya pun kabur. Dengan latar belakang tersebut, penulis tertarik untuk menulis: "Implikasi Yuridis Putusan Mahkamah Konstitusi Nomor 011-017/

Maruarar Siahaan, 2005, Hukum Acara Mahkamah Konstitusi Republik Indonesia, Jakarta, Konstitusi Press, hlm.208. 
PUU-I/2003 Terhadap Perlindungan Hukum Hak Dipilih."

\subsection{Rumusan Masalah}

Berdasarkan latar belakang di atas, masalah dapat dirumuskan sebagai berikut: 1) bagaimana pengaturan perlindungan hukum hak dipilih dalam sistem ketatanegaraan Indonesia? 2) apa implikasi yuridis Putusan Mahkamah Konstitusi Nomor 011-017/ PUU-I/2003 terhadap perlindungan hukum hak dipilih?"

\subsection{Tujuan Penelitian}

\subsubsection{Tujuan Umum}

Tujuan umum dari penelitian ini adalah untuk: a) mengetahui bagaimana pengaturan perlindungan hukum hak dipilih dalam sistem ketatanegaraan Indonesia; b) sebagai bahan dalam pengembangan ilmu hukum terutama terkait implikasi yuridis Putusan Mahkamah Konstitusi Nomor 011-017/UUI/2003 terhadap perlindungan hukum hak dipilih.

\subsubsection{Tujuan Khusus}

Tujuan khusus dari penelitian ini adalah untuk: a) mendekripsikan dan menganalisis pengaturan perlindungan hukum hak dipilih dalam sistem ketatanegaraan Indonesia; b) mendekripsikan dan menganalisis implikasi yuridis Putusan Mahkamah Konstitusi Nomor 011-017/PUU-I/2003 terhadap perlindungan hukum hak dipilih.

\section{METODE PENULISAN}

Metode penelitian pada dasarnya merupakan cara ilmiah untuk mendapatkan data dengan tujuan dan kegunaan tertentu. ${ }^{5}$

Sugiyono, 2013, Cara Mudah Menyusun Skripsi, Tesis dan Disertasi, Bandung, Alfabeta, hml.18.
Jenis penelitian dalam tesis ini menggunakan metode penelitian hukum normatif, ${ }^{6}$ yaitu suatu prosedur penelitian ilmiah untuk menemukan kebenaran berdasarkan logika ilmu hukum dari sisi normatif, terutama berkaitan dengan Putusan Mahkamah Konstitusi Nomor 011-017/PUU- I/2003 yang membatalkan ketentuan Pasal 60 huruf g. Dalam penelitian ini digunakan pendekatan undang-undang (statute approach), yakni meneliti undang-undang yang mempunyai relevansi terkait dengan pemenuhan hak politik, terutamahakdipilih.Pendekatankasus (case approach) digunakan untuk meneliti putusan a quo yang membatalkan ketentuan Pasal 60 huruf g. Selanjutnya, pendekatan konseptual (conceptual approach) dilakukan dengan mempelajari pandangan, konsep, prinsip, norma hukum, baik norma hukum nasional maupun norma hukum internasional (deklarasi dan konvensi), terutama terkait dengan perlindungan hukum hak dipilih.

Sumber bahan hukum yang digunakan dalam penelitian ini adalah sumber bahan hukum primer antara lain: UUD 1945, UU Nomor 39 Tahun 1999, UU Nomor 12 Tahun 2003, UU Nomor 24 Tahun 2003, UU Nomor 10 Tahun 2008, UU Nomor 42 Tahun 2008, Putusan Mahkamah Konstitusi Nomor 011-017/PUU-I/2003, Deklarasi Universal Hak-Hak Asasi Manusia, serta Kovenan Internasional Tentang Hak-Hak Sipil dan Politik. Sedangkan sumber bahan hukum sekunder berupa buku-buku teks, jurnal hukum dan bahan hukum tersier berupa kamus.

Pengumpulan bahan hukum dilakukan melalui inventarisasi. Langkah selanjutnya

Johnny Ibrahim, 2006, Teori \& Metodologi Penelitian Hukum Normatif, Malang. Bayumedia Publishing, hlm.57. 
adalah mengidentifikasi dan mengkaji atau menelaah bahan-bahan hukum dimaksud. Pengolahan dan menganalisis bahan hukum yang terkumpul, baik bahan hukum primer, sekunder maupun tersier dianalisis secara deskriptif. Dengan demikian, tulisan ini bersifat analisis diskriptif.

\section{HASIL DAN PEMBAHASAN}

3.1 Perlindungan Hukum Hak Dipilih dalam Sistem Ketatanegaraan Indonesia

Perlindungan hukum hak dipilih dalam sistem ketatanegaraa Indonesia dapat dicermati dari Pembukaan UUD 1945, Batang Tubuh UUD 1945, dan peraturan perundangan-undangan, termasuk deklarasi maupun konvensi internasional tentang hak asasi manusia, khususnya tentang perlindungan hukum hak dipilih. Dalam konteks ini, hal tersebut tidak dapat dilepaskan dengan konsepsi negara hukum maupun konsepsi kedaukatan rakyat vis $a$ vis merupakan bagian dari hak asasi manusia (HAM) sebagai tercermin dalam Alenia I sampai Alenia IV Pembukaan UUD 1945 dan pasal-pasal dalam Batang Tubuh UUD 1945. Dalam Alenia IV dinyatakan: "Kemudian dari pada itu untuk membentuk suatu pemerintahan Negara Indonesia yang melindungi segenap bangsa Indonesia dan seluruh tumpah darah Indonesia...dalam suatu Undang-Undang Negara Indonesia, yang terbentuk dalam suatu susunan Negara Republik Indonesia yang berkedaulatan rakyat..." Pernyataan tersebut mengandung makna bahwa Konstitusi Negara Republik Indonesia dimana sistem pemerintahan Negara Republik Indonesia didasarkan atas kedaulatan rakyat. Kedaulatan rakyat sering dimaknai sebagai bentuk pemerintahan yang berpaham demokrasi dimana bentuk pemerintahan dan pemerintah dipilih oleh rakyat.

Sejalan dengan uraian tersebut, bila dikaitkan dengan pengaturan perlindungan hukum hak dipilih, maka hal tersebut dapat ditelusuri dalam Pembukaan UUD 1945 dan dalam pasal-pasal dalam Batang Tubuh UUD 1945. Perlindungan hukum menjadi bagian dari hak asasi manusia yang telah diatur dalam Konstitusi Negara Republik Indonesia.

Sebelum menelusuri muatan materi hak asasi manusia, terutama terkait dengan pelindungan hukum hak dipilih dalam sistem ketatanegaraan Indonesia, maka pada uraian berikut diuraikan tentang terminolgi, konsep maupun pandangan tentang perlindungan hukum.

\section{Dalam Kamus Umum Bahasa}

Indonesia karangan WJS Poerwadarminta, diuraikan bahwa perlindungan diartikan sebagai tempatberlindung, darihal (perbuatan dan sebagainya) memperlindungi.?

Perlindungan hukum bagi rakyat di Indonesia sebagai akibat dari tindakan hukum pemerintah ada beberapa kemungkinan, tergantung dari instrumen hukum yang digunakan pemerintah. Instrumen hukum pemerintah yang lazim digunakan adalah suatu peraturan perundang-undangan yang dibentuk atau sebagai produk DPR bersama Presiden. Perlindungan hukum sebagai akibat diterbitkannya peraturan perundangundangan dapat ditempuh melalui permohonan uji materiil (judicial review)

WJS Poerwadarminta, 2003, Kamus Umum Bahasa Indonesia, Jakarta, Balai Pustaka, Cet. XV., Hlm.670. Lihat juga Anton M. Moelyono (Peny.), 1988, Kamus Besar Bahasa Indonesia, Jakarta, Departemen Pendidikan dan Kebudayaan Republik Indonesia,hlm.52. 
ke Mahkamah Agung dan Mahkamah Konstitusi. Permohonan uji materiil (judicial review) yang diajukan ke Mahkamah Agung melingkupi pengujian peraturan perundangundangan di bawah undang-undang (sesuai dengan Pasal 31 ayat (1) UU Nomor 5 Tahun 2004 Tentang Perubahan UU Nomor 14 Tahun 1984 Tentang Mahkamah Agung, LN-RI Tahun 2004 Nomor 9). Sedang permohonan uji materiil (judicial review) ke Mahkamah Konstitusi melingkupi pengujian undang-undang terhadap Undang-Undang Dasar Negara Republik Indonesia Tahun 1945 (sesuai dengan Pasal 10 ayat (1) butir a UU Nomor 24 Tahun 2003 Tentang Mahkamah Konstitusi, LN-RI Tahun 2003 Nomor 98). Oleh karena itu, menurut Saldi Isra bahwa judicial review menjadi salah satu cara untuk menjamin hak-hak kenegaraan yang dimiliki oleh seseorang warga negara pada posisi diametral dengan kekuasaan pembuatan peraturan, termasuk undang-undang. ${ }^{8}$

Pengaturan hak asasi manusia dalam Konstitusi Negara Republik Indonesia diatur dalam Pasal 27 sampai Pasal 34. Pengaturan hak asasi manusia dalam Konstitusi tersebut mengandung makna bahwa negara mengakui keberadaan hak asasi manusia, termasuk perlindungan hukum tentang "bersamaan kedududukan dalam hukum dan pemerintahan". Hal tersebut diatur dalam Pasal 27 ayat (1) UUD 1945. Ketentuan tersebut secara konstitusional dapat dimaknai bahwa setiap warga negara mempunyai kedududukan yang sama di dalam hukum dan pemerintahan. Dalam konteks ini,

Saldi Isra, 2010, Pergeseran Fungsi Legislasi: Menguatnya Model Legislasi Parlementer dalam Sistem Presidensial Indonesia, Jakarta, PT. RajaGrafindo Persada, hlm.293. bunyi ketentuan konstitusional tersebut dapat juga dimaknai bahwa setiap warga negara mempunyai kedudukan yang sama di dalam hukum dan pemerintahan. Setiap warga negara mempunyai hak dipilih yang sama dengan warga Negara lainnya. negara menjamin adanya perlindungan hak asasi manusia, termasuk perlindungan hukum terhadap hak dipilih.

Pengaturan hak asasi manusia dalam UUD 1945 Pasca Perubahan telah mengalami perubahan yang signifikan dan perumusannya menjadi sangat lengkap. Oleh karena itu, Jimly Asshiddiqie menyebut UUD 1945 merupakan salah satu undang-undang dasar yang paling lengkap memuat perlindungan hak asasi manusia. ${ }^{9}$ Pengaturan hak asasi manusia secara khusus diatur dalam Bab XA "Hak Asasi Manusia", dari Pasal 28A sampai Pasal 28J. Pengaturan hak asasi manusia, khususnya terkait perlindungan hukum secara rinci diatur dalam Pasal 28D ayat (1), Pasal 28D ayat (3), dan Pasal 28I ayat (2) UUD 1945 Perubahan Kedua. Secara konstitusional, setiap orang berhak atas pengakuan, jaminan, perlindungan, dan kepastian hukum yang adil serta perlakuan yang sama dihadapan hukum. Demikian pula bahwa setiap warga negara berhak memperoleh kesempatan yang sama dalam pemerintahan. Oleh karena itu setiap orang berhak bebas dari perlakuan yang bersifat diskriminatif atas dasar apa pun dan berhak mendapatkan perlindungan terhadap perlakuan yang bersifat diskkriminatif.

$$
\text { Dari ketentuan konstitusional }
$$
tersebut menunjukkan bahwa negara,

Jimly Asshiddiqie, 2006b, Pengantar Ilmu Hukum Tata Negara (Jilid II), Jakarta, Sekretariat Jenderal dan Kepaniteraan Mahkamah Konstitusi Republik Indonesia, hlm.104-105. 
terutama pemerintah berkewajiban untuk menghormati (to resfect), memenuhi (to fulfill), dan melindungi (to protect) hak asasi manusia setiap warga negara. Dalam kaitan ini, negara memberi pengakuan, jaminan, perlindungan dan kepastian hukum yang adil serta perlakuan yang sama dihadapan hukum. Jaminan atas pelaksanaan hak asasi manusia tersebut sepenuhnya menjadi tanggung jawab negara, khususnya pemerintah. Bagaimana negara menghormati, memenuhi, dan melindungi hak asasi manusia tersebut merupakan tanggung jawabnya. Penegasan terhadap tanggung jawab dan kewajiban tersebut, disebutkan dalam Pasal 28I ayat (4) dimana: ":Perlindungan, pemajuan, penegakan, pemenuhan hak asasi manusia adalah tanggung jawab negara, terutama pemerintah". Sedangkan bagaimana menegakkan dan melindungi hak asasi manusia, disebutkan dalam Pasal 28I ayat (5) dimana: "Untuk menegakkan dan melindungi hak asasi manusia sesuai dengan prinsip-prinsip negara hukum yang demokratis, maka pelaksanaan hak asasi manusia dijamin, diatur dan dituangkan dalam peraturan perundang-undangan”.

Dengan uraian di atas jelas menunjukkan bahwa hak asasi manusia sebagai hak konstitusional (constitutional rights) warga negara telah menjadi tekad dan komitmen negara untuk menghormati, memenuhi, dan melindunginya. Oleh karena itu menjadi kewajiban dan tanggung jawab negara untuk menghormati, memenuhi, dan melindungi hak asasi manusia tersebut.

Sejalan dengan uraian di atas, sesungguhnya UUD 1945 Perubahan Pertama sampai Keempat (dari tahun 1999 sampai tahun 2002) merupakan produk Gerakan Reformasi dimana rakyat dan bangsa Indonesia menuntut diadakannya amandemen terhadap UUD 1945. Materi muatan UUD 1945 tidak dapat dilepaskan dari tekad dan semangat rakyat, bangsa Indonesia, termasuk lembaga-lembaga Negara dan seluruh Aparatur Pemerintahan untuk menghormati, menegakkan dan menyebarluaskan pemahaman mengenai hak asasi manusia. Tekad dan semangat tersebut tertuang dalam Tap MPR-RI Nomor XVII/MPR/1998. Dalam perkembangan selanjutnyadan sekaligus sebagaitindaklanjut atas tekad dan semangat tersebut tercermin dalam UU Nomor 39 Tahun 1999 yang disahkan pada tanggal 23 September 1999 (LN-RI Tahun 1999 Nomor 165) sebagai salah satu undang-undang yang secara khusus mengatur tentang hak asasi manusia. Jika ditelusuri materi muatan UU Nomor 39 Tahun 1999 tersebut, ternyata diadopsi menjadi materi muatan UUD 1945 Perubahan Kedua, khususnya terkait tentang hak asasi manusia. Namun, dalam UU Nomor 39 Tahun 1999 secara khusus dimuat ketentuan normatif terkait tentang "hak dipilih" sebagai diuraikan pada "Bagian Kedelapan: Hak Turut Serta dalam Pemerintahan" dalam Pasal 43 ayat (1) dan ayat (2).

Adanya ketentuan Pasal 43 ayat (1) dan ayat (2) tersebut menunjukkan bahwa perlindungan hukum hak dipilih sebagai hak setiap warga negara wajib dilindungi. Untuk mengimplementasikan hak dipilih sebagai bagian dari hak asasi manusia tersebut ditentukan dalam peraturan perundanganundangan dan dengan tetap berpegang melalui mekanisme pemungutan suara yang mengedepankan asas langsung, umum, bebas , dan rahasia serta judul dan adil (asas luber dan jurdil). 
Pada bagian lain harus diakui bahwa Negara Republik Indonesia sebagai negara merdeka memang tidak dapat dilepaskan dengan norma-norma hukum internasional. Dalam hal ini termasuk deklarasi maupun konvensi internasional tentang hak asasi manusia. Dengan demikian, sebagaimana diuraikan sebelumnya bahwa Proklamasi Kemerdekaan Negara Republik Indonesia pada tanggal 17 Agustus 1945 sebagai tercermin dalam Pembukaan UUD 1945 sarat dengan kandungan amanat kemerdekaan, kebebasan, kesetaraan, dan keadilan. Sebagai Negara yang diproklamasikan dalam suasana Perang Dunia II, maka suasana yang berkembang di dunia internasional menjadi perhatian dan kepedulian para founding fathers bangsa ketika itu. Masyarakat internasional melalui Majelis Umum Perserikatan Bangsa-Bangsa telah mencetuskan Deklarasi Universal HakHak Asasi Manusia (Universal Declaration of Human Rights) pada tanggal 10 Desember 1948. DUHAM terdiri atas 30 pasal, tidak saja memuat hak sipil dan hak politik melainkan hak ekonomi, hak sosial, dan hak budaya. Dalam konteks hak dipilih sebagai bagian dari hak politik, dalam DUHAM diatur dalam Pasal 21 ayat (1), ayat (2), dan ayat (3).

Apa yang ditentukan dalam Pasal 21 DUHAM tersebut memberikan landasan moral bagi setiap negara untuk memberikan penghormatan, jaminan dan pemenuhan, dan perlindungan terhadap hak-hak politik, terutama hak dipilih bagi setiap warga negara. Pelibatan dalam pemerintahan, baik secara langsung maupun tidak langsung merupakan hak. Untuk mewujudkan hak politik tersebut, setiap warga negara mempunyai kesempatan dan kedudukan hukum yang sama. Tidak ada perlakuan diskriminatif.
Setelah munculnya DUHAM, pada tahun 1966 PBB mengeluarkan Kovenan Internasional Tentang Hak-Hak Sipil dan Politik (International Covenant on Civil and Political Rights/ ICCPR). Pada hakekatnya munculnya $I C C P R$ ini tidak lain adalah untuk memberi perhatian dan perlindungan terhadap hak asasi manusia, khususnya terkait dengan hak sipil dan hak politik yang menjadi fondasi bagi terpenuhi dan terwujudnya hak-hak asasi manusia, terutama hak sipil dan hak politik wargan negara. Hak dipilih sebagai bagian dari hak politik, dalam ICCPR ditentukan dalam Pasal 25 butir (a), butir (b), dan butir (c).

Dengan ketentuan Pasal 25 ICCPR tersebut menunjukkan bahwa setiap warga negara mempunyai hak dan kesempatan yang sama tanpa ada perbedaan dalam menjalankan hak politiknya, terutama dalam menggunakan hak dipilih. Penggunaan hak dipilih tersebut dilakukan melalui mekanisme Pemiliham Umum. Mekanisme dimaksud tetap berpegang pada asas kerahasian dan bebas untuk memilih sesuai kehendak para pemilih.

Berdasarkan uraian di atas, nampaklah bahwa pengaturan perlindungan hukum hak dipilih dalam sistem ketatanegaraa Indonesia tidak saja tercermin dalam Pembukaan UUD 1945 dan Batang Tubuh UUD 1945 melainkan juga diatur dalam peraturan perundang-undangan, baik dalam Tap MPRRI Nomor XVII/MPR/1998, UU Nomor 39 Tahun 1999 maupun dalam DUHAM dan ICCPR. 


\subsection{Implikasi Yuridis Putusan Mahkamah Konstitusi Nomor 011- 017/PUU-I/2003}

Dalam Pasal 10 ayat (1) UU Nomor 24 Tahun 2003 ditentukan bahwa Mahkamah Konstitusi berwenang mengadili pada tingkat pertama dan terakhir yang putusannya bersifat final. Selanjutnya dalam Pasal 47 ditentukan bahwa putusan Mahkamah Konstitusi memperoleh kekuatan hukum tetap sejak selesai diucapkan dalam sidang pleno terbuka untuk umum. Itu berarti bahwa putusan Mahkamah Konstitusi langsung memperoleh kekuatan hukum tetap sejak diucapkan dan tidak ada upaya hukum yang dapat ditempuh. ${ }^{10}$ Oleh karena itu, putusan Mahkamah Konstitusi bersifat final and binding.

Kekuatanmengikat putusanMahkamah Konstitusi berbeda dengan putusan peradilan biasa. Kekuatan mengikat tidak hanya bagi pihak-pihak yang berperkara, seperti: Pemohon, Termohon, Pemerintah, DPR/ DPD ataupun pihak terkait yang diizinkan memasuki proses perkara melainkan juga mengikat bagi semua orang, lembaga negara dan badan hukum dalam wilayah Republik Indonesia. Putusan dimaksud berlaku sebagai hukum sebagaimana hukum dibentuk oleh pembentuk undang-undang (DPR bersama Presiden). Hakim Mahkamah Konstitusi dikatakan sebagai Negative Legislator yang putusannya bersifat erga omnes yang ditujukan pada semua orang. ${ }^{11}$

Pada analisis berikut, terutama terkait dengan Putusan Mahkamah Konstitusi Nomor 011-017/PUU-I/2003 berikut diuraikan tentang: a) implikasi yuridis hanya pada lembaga perwakilan, b) Implikasi

Maruarar Siahaan, 2005, Ibid., hlm.208.

Maruarar Siahaan, Ibid. yuridis terhadap perlindungan hukum hak dipilih.

\subsubsection{Implikasi Yuridis Putusan Hanya pada Lembaga Perwakilan}

Keberadaan hak dipilih telah diakomodasi dalam Pemilihan Umum Legislatif. Dalam hal ini meski sesungguhnya permasalahan berhubungan dengan hak dipilih, namun pada dasarnya adalah untuk semuajabatan publik. Pasal 60 hurufg dicabut ataudibatalkankeberlakuannyasesuaidengan Putusan Mahkamah Konstitusi Nomor 011017/PUU-I/2003 tanggal 24 Februari 2004 seharusnya dijadikan landasan yuridis oleh pembentuk undang-undang (DPR bersama Presiden). Dalam pembentukan undangundang berikutnya, terutama UU Nomor 10 Tahun 2008 Tentang Pemilihan Umum Anggota Dewan Perwakilan Rakyat, Dewan Perwakilan Daerah, dan Dewan Perwakilan Rakyat Daerah (LN-RI Tahun 2008 Nomor 51) tidak lagi mencantumkan persyaratan sebagaimana dimaksud Pasal 60 huruf g UU Nomor 12 Tahun 2003 (Pasal 12 UU Nomor 10 Tahun 2008). Dengan demikian, implikasi yuridis Putusan Mahkamah Konnstitusi Nomor 011-017/PUU-I/2003 terhadap perlindungan hukum hak dipilih nampak konkret dalam UU Nomor 10 Tahun 2008, yaitu dengan tidak lagi mencantumkan persyaratan yang diskriminatif. Pembentuk undang-undang, baik DPR bersama Presiden menjadikan Putusan Mahkamah Konstitusi tersebut sebagai landasan yuridis dalam membentuk undang-undang.

Namun, semangat berbeda terlihat manakala DPR bersama Presiden membentuk undang-undang selain UU Nomor 10 Tahun 2008 dimana untuk jabatan publik yang bersifat strategis masih mencantumkan 
persyaratan "terlibat secara langsung atau tidak langsung dengan pemberontakan PKI".

Adanya kalimat "terlibat langsung atau tidak langsung dengan pmberontakan PKI" dimaknai sebagai bekas anggota organisasi terlarang PKI, termasuk organisasi massanya, atau bukan orang yang terlibat langsung dalam G.30.S/PKI. Dalam konteks ini, pencantuman persyaratan tersebut terdapat pada syarat calon Presiden dan Wakil Presiden sebagaimana dimaksud dalam Pasal 5 huruf q UU Nomor 42 Tahun 2008.

Dalam perspektif hak asasi manusia, pencantuman persyaratan sebagaimana dimaksud Pasl 5 huruf q UU Nomor 42 Tahun 2008 bertentangan dengan hak konstitusional (constitutional rights) warga negara, baik sebagaimana ditentukan dalam Konstitusi Negara Republik Indonesia, peraturan perundang-undangan Indonesia maupun dalam instrumen internasional tentang hak asasi manusia. Dalam Konstitusi Negara Republik Indonesia, negara terutama pemerintah menjamin penghormatan, pemenuhan, dan perlindungan terhadap hakhak asasi manusia, terutama memberikan perlindungan hukum hak dipilih kepada setiap warga negara. Oleh karena hak asasi manusia merupakan hak konstitusional (constitutional rights) warga negara, maka telah seharusnya menjadi dasar dalam pengakomodasian hak-hak warga negara dalam persamaan kedudukan hukum dan pemerintahan, termasuk untuk mencalonkan diri sebagai pemimpin tertinggi negeri ini, yaitu sebagai Calon Presiden dan Calon Wakil Presiden dalam suatu Pemilihan Umum.
Kondisi sebagaimana dikemukakan di atas merupakan bentuk diskriminasi dalam bidang politik. Diskriminasi dalam konteks ini merujuk kepada perlakuan yang tidak adil terhadap individu warga negara tertentu. Secara umum, diskriminasi memberlakukan perbedaan peraturan atas pemberlakuan secara tidak adil, baik terkait suku, ras, agama, antar golongan, kelamin, kondisi fisik, kepercayaan, aliran politik, dan lainnya.

Dalam perspektif Pemilihan Umum Presiden dan Wakil Presiden yang didasarkan pada UU Nomor 42 Tahun 2008 yang masih mencumkan persyaratan calon Presiden dan calon Wakil Presiden harus bebas dari keanggotaan PKI maupun simpatisannya merupakan bentuk perlakuan diskriminasi terhadap hak politik warga negara. Kondisi tersebut tidak boleh terjadi, apalagi kebijakan diskriminatif tersebut dilakukan oleh negara. Negara sebagai pihak yang seharusnya menghormati, memenuhi, melindungi, dan bertanggung jawab untuk memastikan terpenuhinya hak konstitusional (constitutional rights) warga negara tersebut berlaku tanpa diskriminasi.

Dalam konteks rekruitmen kepemimpinan seharusnya direfleksikan pada pengakomodasian seluruh warga negara untuk secara sehat, fair dan terbuka berkompetisi didasarkan pada hak asasi manusia yang menekankan tidak ada pembatasan, penyimpangan, dan perlakuan diskriminasi.PemilihanUmumsebagaisarana perwujudan demokrasi tidak seharusnya ternodai dengan adanya pembatasan hak partisipasi politik warga negara. Ketentuan UU Nomor 42 Tahun 2008 tersebut sudah tidak relevan dalam menumbuhkan budaya hukum yang demokratis sejalan dengan 
konsepsi Negara Republik Indonesia sebagai Negara hukum.

Dalam perspektif ini kiranya Putusan a quo tersebut seharusnya dijadikan sebagai landasan untuk mengakomodasikan hak warga negara, terutama hak dipilih dalam Pemilihan Umum Presiden dan Wakil Presiden dan Pemilihan Umum untuk jabatan publik yang lainnya. Dengan demikian, pengakomodasian atas Putusan a quo harus diperluas, sehingga tidak saja menjadi landasan yuridis untuk Pemilihan Umum anggota legislatif melainkan untuk semua jabatan publik, baik pada bidang legislatif, eksekutif (dalam hal ini Presiden dan Wakil Presiden) maupun pada jabatan yudikatif.

Sebagai instrumen internasional yang juga diakomodasikan dalam sistem penegakan dan perlindungan hak asasi manusia di Indonesia, maka ketentuan hukum sebagaimana diatur dalam Pasal 25 huruf b Kovenan Internasional Tentang HakHak Sipil dan Politik yang telah diratifikasi melalui UU Nomor 12 Tahun 2005 Tentang Pengesahan International Covenant on Civil and Political Rights (Kovenan Internasional Tentang Hak-Hak Sipil dan Politik, LN-RI Tahun 2005 Nomor 119).

Berdasarkan uraian di atas, dapat dimaknai bahwa terkait adanya perlakuan diskriminatif terhadap hak asasi manusia, termasuk tentang hak dipilih sebagai bagian hak politik tentu tidak ada interpretasi lain selain mencabut ketentuan tersebut. Artinya, bagi Negara, termasuk pemerintah tidak ada argumentasi yang membenarkan adanya pembatasan hak politik mantan anggota PKI dan simpatisannya. Negara seharusnya menghormati, memenuhi, dan melindungi hak dipilih warga negara sebagai bagian dari hak asasi manusia. Dalam konteks ini, untuk menghormati, memenuhi, dan melindungi hak dipilih merupakan tanggung jawab negara, khususnya pemerintah. Oleh karena itu, adanya Putusan a quo telah mencabut ketentuan yang dianggap berlaku diskriminatif, bertentangan dengan hak konstitutional (constitutional rights) warga negara seharusnya dijadikan referensi dalam pembentukan undang-undang ke depan. Dengan kalimat lain, hendaknya hak dipilih dapat diakomodasikan tanpa adanya pembatasan-pembatasan yang bertentangan dengan hak asasi manusia.

\subsubsection{Implikasi Yuridis dalam Bidang Politik untuk Hak Dipilih}

Pada prinsipnya pendapat para Hakim Konstitusi yang kemudian dituangkan dalam putusan pada permohonan uji materiil (judicial review) tersebut sangat tepat meski ada salah satu Hakim Konstitusi berpendapat berbeda (dissenting opinion). Bahwa secara tersurat dan tegas tanpa harus ada pernafsiran terhadap ketentuan Pasal 1 ayat (3) UUD 1945 Perubahan Kedua dinyatakan: "Negara Indonesia adalah negara hukum." Dengan adanya ketentuan Pasal 60 huruf g tersebut dimana warga negara yang hak konstitusionalnya dibatasi berhak mengajukan uji material (judicial review) ke Mahkamah Konstitusi.

Meskipun secara praktis UU Nomor 12 Tahun 2003 sudah diubah dengan UU Nomor 10 Tahun 2008, namun dalam konteks ini relevan untuk dikedepankan. Kedua undangundang tersebut sesungguhnya merupakan implementasi konkret atas ketentuan Pasal 1 ayat (3) UUD 1045 Perubahan Kedua. Dengan demikian, ketentuan tersebut menurut Jimly Asshiddiqie mengandung pengertian substansial sebagai:

1) 
Pengakuan terhadap supremasi hukum dan konstitusi; 2) Dianutnya prinsip pemisahan dan pembatasan kekuasaan menurut sistem konstitusional yang diatur dalam UUD 1945; 3) Adanya jaminan hak asasi manusia dalam UUD 1945; 4) Adanya prinsip peradilan yang bebas dan tidak memihak yang menjamin persamaan setiap warga negara dalam hukum; 5) Menjamin keadilan bagi setiap orang termasuk terhadap penyalahgunaan wewenang oleh pihak yang berkuasa. ${ }^{12}$

Uraian Negara hukum tersebut sejalan dengan pengertian Rechtsstaat dimana menurut Freidrich Julius Stahl mensyaratkan beberapa prinsip meliputi: 1) Perlindungan hak asasi manusia (grondrechten); 2) Pembagian kekuasaan (scheiding van machten); 3) Pemerintahan berdasarkan undang-undang (wetmatigheid van bestuur); dan 4) Adanya peradilan administrasi Tata Usaha Negara (administratieve rechtspraak). ${ }^{13}$

Dalam konteks ini dapat dimaknai bahwa dalam suatu negara hukum, salah satu pilar terpentingnya adalah adanya penghormatan, pemenuhan, perlindungan, dan jaminan terhadap hak asasi manusia (HAM). Tanpa adanya penghormatan, pemenuhan, perlindungan, dan jaminan terhadap hak asasi manusia (HAM), maka negara hukum tersebut akan kehilangan maknanya. Dengan kalimat lain, ada keterkaitan yang tidak bisa dipisahkan antara negara hukum, jaminan dan perlindungan terhadap hak asasi manusia (HAM).

12 Jimly Asshiddiqie, 1994, Gagasan Kedaulatan Rakyat dalam Konstitusi dan Pelaksanaannya di Indonesia, Jakarta, Ichtiar Baru Van Hoeve, hlm.79.

13 Philipus M. Hadjon, 1988, Pengkajian Ilmu Hukum, Surabaya, Program Pascasarjana Universitas Airlangga, hlm.23.
Perlindungan terhadap hak asasi manusia dimasyarakatkan secara luas dalam rangka mempromosikan penghormatan (to respect), perlindungan (to protect), dan pemenuhan (to fulfill) terhadap hak asasi manusia sebagai ciri penting bagi suatu negara hukum yang demokratis. ${ }^{14}$ Makna substansialnya bahwa setiap manusia sejak kelahirannya menyandang hak-hak dan kewajiban-kewajiban yang bersifat bebas dan asasi.

Penyelenggaraan kekuasaan suatu negara tidak boleh mengurangi arti atau makna kebebasan dan hak asasi manusia. Penyelenggaraan pemerintahan negara yang mengurangimaknajaminan dan perlindungan terhadap hak-hak warga negara dapat dimaknai telah melanggar hak asasi manusia. Kondisi tersebut merupakan refleksi dari sistem pemerintahan yang otoriter dan keluar dari prinsip negara hukum.

Sejalan dengan hal tersebut, negara berkewajiban dalam mempromosikan penghormatan, pemenuhan, perlindungan, dan jaminan terhadap hak asasi manusia. Pada dasarnya negara dibentuk untuk menjamin pelaksanaan prinsip-prinsip hak asasi manusia. Hal ini menjadi tujuan pokok dan utama dibentuknya negara, yaitu melindungi, menghormati, dan memenuhi hak asasi manusia.

Berdasarkan uraian tersebut, pada prinsipnya pembatasan untuk berperan serta sebagai calon dalam pencalonan jabatan publik dengan menggunakan hak dipilih, khususnya Presiden dan Wakil Presiden seharusnya juga mengacu pada Putusan $a$ $q u o$ tersebut. Peraturan perundang-undangan dan peraturan lain yang membatasi atau

14 Munasir., 2003, Hak Politik dalam Perspekltif Hak Asasi Manusia, Solo, Penepen Mukti,hlm.65. 
yang meniadakan hak pencalonan dimaksud merupakan pembatasan terhadap hak dipilih sebagai hak politik warga negara. Tindakan pembatasan atau peniadaan tersebut merupakan bentuk perlakuan diskriminasi yang bertentangan dengan Konstitusi Negara Republik Indonesia.

Interprertasi demikian merupakan perwujudan negara hukum yang menekankan pada tidak adanya diskriminasi. Setiap warga Negara mempunyai berkedudukan sama di dalam hukum dan pemerintahan (Pasal 27 ayat (1) UUD 1945, Pasal 28D ayat (1) dan ayat (3), serta Pasal 28I ayat (2) UUD 1945 Perubahan Kedua). Hak dicalonkan atau hak dipilih terbebas dari perlakuan diskriminasi. Hal ini yang menjadi dasar dari pencabutan terhadap ketentuan Pasal 60 huruf g UU Nomor 12 Tahun 2003. Dengan demikian, implikasi yuridis dalam bidang politis untuk hak dipilih adalah tidak adanya perlakuan diskriminasi dalam setiap produk legislatif yang dibentuk oleh DPR bersama Presiden maupun produk peraturan perundangundangan lainnya.

\section{V. PENUTUP}

\subsection{Simpulan}

Berdasarkan uraian tersebut, dapat disimpulkan hal-hal sebagai berikut:

1. Perlindungan hukum hak dipilih dalam sistem ketatanegaraan Indonesia dapat ditelusuri dari Pembukaan UUD 1945, Pasal-Pasal dalam Batang Tubuh, terutama Pasal 27 ayat (1), Pasal 28D ayat (1) dan ayat (3), serta Pasal 28I ayat (2) UUD 1945 Perubahan Kedua, Tap MPR RI Nomor XVII/MPR/1998, Pasal 43 UU Nomor 39 Tahun 1999, Pasal 21 Deklarasi Univeral Hak Asasi Manusia, dan Pasal 25 Kovenan
Internasional Tentang Hak-Hak Sipil dan Politik.

2. Implikasi yuridis Putusan Mahkamah Konstitusi Nomor 011-017/PUUI/2003 terhadap perlindungan hukum hak dipilih meliputi:

a) Implikasi yuridis hanya pada lembaga perwakilan ditandai dengan tidak dicantumkan lagi sebagai persyaratan sebagai dimaksud Pasal 60 huruf g UU Nomor 12 Tahun 2003 dan dalam UU Nomor 10 Tahun 2008.

b) Implikasi yuridis bidang politik untuk hak dipilih adalah tidak adanya perlakuan diskriminasi dalam setiap produk legislatif yang dibentuk oleh DPR bersama Presiden maupun produk peraturan perundang-undangan lainnya ke depan.

\subsection{Saran}

Berdasarkan uraian dan simpulan di atas, disarankan hal-hal sebagai berikut:.

1. Hendaknya peraturan perundangundangan atau aturan yang dibentuk oleh DPR bersama Presiden tidak berlaku diskriminatif.

2. Hendaknya dengan adanya Putusan Mahkamah Konstitusi Nomor 011017/PUU-I/2003 tersebut, dalam pembentukan undang-undang oleh DPR bersama Presiden tidak semata ditujukan untuk pembentukan undangundang legislatif melainkan untuk undang-undang jabatan publik, termasuk untuk jabatan calon Presiden dan calon Wakil Presiden. 


\section{DAFTAR PUSTAKA}

\section{BUKU}

Asshiddiqie, Jimly, 1994. Gagasan

Kedaulatan Rakyat dalam Konstitusi dan Pelaksanaannya di Indonesia, Ichtiar Baru Van Hoeve, Jakarta.

------------, 2006a, Sengketa Kewenangan

Antar Lembaga Negara, Konstitusi

Press, Cet. I, Jakarta. 2006b, Pengantatr Ilmu

Hukum Tata Negara (Jilid II),

Sekretariat Jenderal dan Kepaniteraan

Mahkamah Konstitusi, Jakarta.

Gaffar, Jenedjri M, 2012, Politik Hukum

Pemilu, Konstitusi Press, Jakarta.

Hadjon, Philipus M, 1988, Pengkajian

Ilmu Hukum, Program Pascasarjana,

Universitas Airlangga, Surabaya.

Ibrahim, Johnny, 2006, Teori \& Metodologi

Penelitian Hukum Normatif,

Bayumedia Publishing, Malang.

Isra, Saldi, 2010, Pergeseran Fungsi

Legislasi: Menguatnya Model

Legislasi Parlementer dalam

Sistem Presdensial Indonesia, PT.

RajaGrafindo Persada, Jakarta.

Moelyono, Anton M., 1988, Kamus Besar

Bahasa Indnesia, Departemen

Pendidikan dan Kebudayaan Republik

Indonesia, Jakarta.

Munasir, 2003, Hak politik dalam Perspekif

Hak Asasi Manusia, Penepen Mukti,

Solo.

Poerwadarminta, WJS., 2003, Kamus

Umum Bahasa Indonesia, Balai

Pustaka, Cet. XV, Jakarta.

Siahaan, Maruarar, 2005, Hukum Acara

Mahkamah Konstitusi Republik

Indonesia, Konstitusi Press, Jakarta.
Sugiyono, 2013, Cara Mudah Menyusun

Skripsi, Tesis dan Disertasi, Alfabeta, Bandung.

\section{PERATURAN PERUNDANG}

UNDANGAN

Undang-Undang Dasar Negara Republik Indonesia Tahun 1945.

Ketetapan MPR-RI Nomor XVII/MPR/1998

Tentang Hak Asasi Manusia.

Undang-Undang Nomor 39 Tahun 1999

Tentang Hak Asasi Manusia.

Undang-Undang Nomor 12 Tahun 2003

Tntang Pemilihan Umum Anggota

Dewan Perakilan Rakyat, Dewan

PerwakilanDaerah,DewamPerwakilan

Rakyat Daerah.

Undang-Undang Nomor 24 Tahun 2003

Tentang Mahkamah Konstitusi

Republik Indonesia.

Undang-Undang Nomor 10 Tahun 2008

Tentang Pemilihan Umum Anggota

Dewan Perwakilan Rakyat, Dewan

Perwakilan Daerah, Dewan Perwakilan

Rakyat Daerah.

Undang-Undang Nomor 42 Tahun 2008

Tentang Pemilihan Umum Presiden dan Wakil Presiden.

Putusan Mahkamah Konstitusi Nomor 011017/PUU-I/2003 